\title{
Optimasi Pola Tanam Pada lahan Sawah Tadah Hujan Di Kecamatan Cimanggung KABUPATEN SUMEDANG
}

\section{Optimization of Cropping Patterns on Rainfed Land in Cimanggung Sub-District Of Sumedang District}

\author{
Sophia Dwiratna N.P. ${ }^{1)}$, Edy Suryadi ${ }^{1)}$, Kharisma Dewi Kamaratih ${ }^{1)}$ \\ 1) Departemen Teknik Pertanian dan Biosistem, FTIP, Universitas Padjadjaran \\ Jalan Raya Bandung-Sumedang Km 21, Jatinangor 40600 \\ Email : sophia.dwiratna@unpad.ac.id
}

\begin{abstract}
ABSTRAK
Lahan sawah tadah hujan hanya mengandalkan hujan untuk pemenuhan kebutuhan air. Penentuan pola dan jadwal tanam sangat diperlukan agar kegagalan panen dapat dihindari sehingga keuntungan maksimum dapat diperoleh. Penelitian ini bertujuan untuk mengetahui pola dan jadwal tanam lahan sawah tadah hujan yang sesuai dengan kesetimbangan air dan menghasilkan keuntungan maksimum bagi petani di Kecamatan Cimanggung Kabupaten Sumedang. Metode penelitian yang digunakan dalam penelitian ini adalah metode deskriptif, yaitu mengkaji data curah untuk mengetahui ketersediaan air, menentukan pola dan jadwal tanam yang sesuai dengan ketersediaan air, dan menentukan pola tanam yang dapat menghasilkan keuntungan maksimum dengan menggunakan program linier. Hasil penelitian menunjukkan bahwa jadwal tanam yang terbaik untuk Kecamatan Cimanggung adalah November dasarian II (MT I) dan Februari dasarian III (MT II) dengan pola tanam: Padi-Padi; Padi-Jagung; Padi-Tembakau; PadiTimun; Padi-Jagung Manis; dan Jagung-Jagung. Berdasarkan analisis optimasi, pola tanam yang memberikan keuntungan maksimum adalah Padi-Timun.
\end{abstract}

Kata kunci : Sawah Tadah Hujan, Pola dan Jadwal Tanam, Neraca Air, Optimasi.

\section{ABSTRACT}

Rainfed land only depend on rainfall for supply water requirement. Determination of cropping patterns and planting schedule is needed to prevent a failure cropping. This study is aimed to determine the cropping patterns and planting schedule according to the water balance, and determine cropping patterns that can gives the maximum profit in Cimanggung Sub-District of Sumedang District. The research method used in this study is descriptive method, which examines the rainfall data to determine the amount of water, determine the cropping patterns and planting schedule according to the water balance, and use the linear programming to determine cropping patterns that can gives the maximum profit. The results showed that the best planting schedule for Cimanggung Sub-District of Sumedang District is decade II of November (MT I) and decade III of Februari (MT II) with cropping pattern that allows: Rice-Rice; Rice-Corn; Rice-Tobacco; RiceCucumber; Rice-Sweet Corn, and Corn-Corn. Based on the analysis of the optimization, cropping pattern that gives the maximum profit is the Rice-Cucumber.

Keywords : Rainfed Land, Cropping Patterns and Planting Schedule, Water balanced, Optimization.

Diterima ; 2 Juli 2016; Disetujui : 29 Agustus 2016 ; Online Published : 31 Oktober 2016 


\section{PENDAHULUAN}

Seiring dengan banyaknya lahan pertanian yang dialihfungsikan, maka berkurang pula hasil yang dapat diperoleh dari sektor pertanian, sehingga mengakibatkan terganggunya ketahanan pangan. Salah satu cara untuk menanggulangi masalah tersebut adalah dengan perencanaan pertanian yang baik.

Perencanaan tanam termasuk dalam kegiatan perencanaan pertanian. Menurut Talitha (2010), perencanaan tanam dapat dilakukan dengan mengatur pola tanam. Pola tanam yang baik akan menghasilkan produksi yang baik dengan memaksimalkan ketersediaan air yang ada untuk memenuhi kebutuhan air dari pola tanam itu sendiri.

Kebutuhan air tanaman dapat dipenuhi dengan dua cara, yaitu dengan hujan dan irigasi. Areal pertanian yang sangat membutuhkan air adalah sawah. Terdapat dua macam sawah, yaitu sawah pengairan (irigasi) dan sawah tadah hujan. Sawah pengairan mendapatkan pemenuhan air dari sumber air irigasi seperti sungai, waduk atau embung.Sedangkan sawah tadah hujan hanya mengandalkan hujan sebagai sumber pengairan utama.

Gagal panen dan gagal tanam merupakan hal yang sangat lumrah dialami oleh petani tadah hujan, contoh : petani menugal pada saat kondisi lengas tanah sangat rendah dengan keyakinan besok atau lusa akan turun hujan yang cukup untuk memulai pertumbuhan padi di sawahnya. Akan tetapi apabila perkiraan petani salah maka benih yang ditugal tidak akan tumbuh atau bibit yang baru saja tumbuh segera mati karena kekeringan (Pramudia et al, 1991).

Kecamatan Cimanggung merupakan daerah yang sebagian besar penduduknya merupakan petani. Lahan pertanian di daerah tersebut semakin menurun dikarenakan banyaknya lahan pertanian produktif yang dialihfungsikan menjadi kawasan industri.Umumnya jadwal tanam dilakukan dua kali dalam setahun, yaitu musim tanam pertama (MT I) dimulai pada bulan Oktober ditanami padi sawah, Musim tanam kedua (MT
II) dimulai pada bulan Maret ditanami padi/palawija (Kecamatan Cimanggung, 2009). Umumnya petani menerapkan pola dan jadwal tanam berdasarkan pengalaman. Namun dengan perubahan iklim global yang terjadi saat ini, pola dan jadwal tanam yang biasa diterapkan petani sudah tidak dapat diberlakukan seperti biasanya.Seringkali lahan petani mengalami kekeringan akibat salah memprediksi iklim yang pada akhirnya berdampak pada ekonomi petani. Kondisi ekonomi petani akan berkaitan dengan modal, dan modal tersebut selalu menjadi masalah yang sering dihadapi petani saat musim tanam berikutnya tiba. Hal tersebut menunjukkan bahwa pola tanam yang biasa digunakan petani belum dapat menghasilkan keuntungan yang maksimum.

Sehubungan dengan permasalahan di atas, maka diperlukan penelitian tentang pola dan jadwal tanam untuk lahan sawah tadah hujan. Penentuan jadwal dan pemilihan varietas tanaman yang sesuai dengan ketersediaan air di lahan pada setiap musim tanam, maka masalah defisit air dan kegagalan panen dapat dihindari. Selain itu dengan pemilihan tanaman yang memiliki nilai jual yang tinggi, petani akan mendapatkan keuntungan yang maksimal. Untuk mengetahui pola tanam yang dapat memberikan keuntungan maksimum, diperlukan analisis optimasi menggunakan program linier.

\section{METODOLOGI PENELITIAN}

Metode penelitian yang digunakan adalah metode deskriptif, yaitu mengkaji :

1. Data curah hujan untuk mengetahui ketersediaan air dan data koefisien tanaman untuk mengetahui kebutuhan air tanaman. Perbandingan ketersediaan air dengan kebutuhan air tanaman dapat digunakan untuk menganalisis neraca air.

2. Pola dan Jadwal tanam yang ditentukan berdasarkan neraca air umum. Pemilihan tanaman mengacu pada kebiasaan petani, namun disesuaikan dengan ketersediaan air.

3. Optimasi pemrograman linier pada pola tanam sehingga menghasilkan pola tanam dengan keuntungan maksimum.

38 Optimasi Pola Tanam Pada Lahan Sawah Tadah Hujan Di Kecamatan Cimanggung Kabupaten Sumedang 


\section{Tahapan Penelitian}

Metode penelitian ini mengikuti tahapan yang disajikan dalam Gambar 1 berikut :

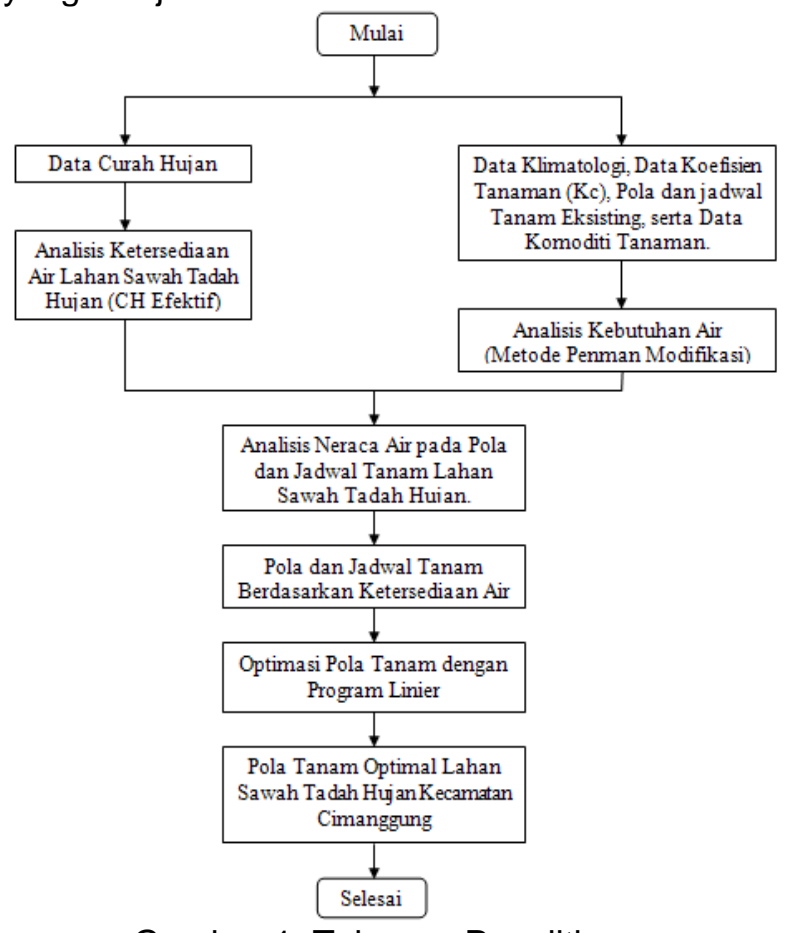

Gambar 1. Tahapan Penelitian

\section{Analisis Data}

\section{1) Analisis Data Ketersediaan Air}

a. Menentukan curah hujan wilayah dengan menggunakan persamaan :

$\mathrm{R}=\frac{\mathrm{R}_{1} \mathrm{~A}_{1}+\mathrm{R}_{2} \mathrm{~A}_{2}+\mathrm{R}_{3} \mathrm{~A}_{3}+\mathrm{R}_{4} \mathrm{~A}_{4}}{\mathrm{~A}_{1}+\mathrm{A}_{2}+\mathrm{A}_{3}+\mathrm{A}_{4}}$

$\mathrm{R}=\mathrm{R}_{1} \mathrm{~W}_{1}+\mathrm{R}_{2} \mathrm{~W}_{2}+\mathrm{R}_{3} \mathrm{~W}_{3}+\mathrm{R}_{4} \mathrm{~W}_{4}$

Keterangan :

$R \quad$ = Hujan rata-rata;

$\mathrm{R}_{1}, \mathrm{R}_{2}, \ldots, \mathrm{R}_{\mathrm{n}}$ = Curah hujan untuk masingmasing alat penakar hujan $(\mathrm{mm})$;

$A_{1}, A_{2}, \ldots, A_{n}=$ Luas untuk masing-masing daerah poligon (ha);

A $=$ Luas total daerah tangkapan air (ha);

$\mathrm{W}_{1}, \mathrm{~W}_{2}, \ldots, \mathrm{W}_{\mathrm{n}}=$ Faktor bobot (weighing) masing-masing stasiun yaitu $\%$ daerah pengaruh terhadap luas keseluruhan. b. Menentukan curah hujan efektif $\left(R_{e}\right)$ dari tahun dasar curah hujan andalan yang dipilih. Perhitungan curah hujan efektif dilakukan dengan metode USDA Soil Conservation Service dengan menggunakan persamaan :

$\operatorname{Re}=R_{\text {dec }} \times\left(125-0,6 \times R_{\text {dec }}\right) / 125$, untuk $R_{\text {dec }} \leq(250 / 3) \mathrm{mm}$ dan,

$\operatorname{Re}=(125 / 3)+0,1 \times R_{\text {dec }}$, untuk $R_{\text {dec }}>$ $(250 / 3) \mathrm{mm}$.

\section{2) Analisis Data Kebutuhan Air Tanaman}

Besarnya kebutuhan air tanaman dinyatakan sama dengan besarnya evapotranspirasi tanaman yang diperoleh dari persamaan :

$$
E T_{c}=K_{c} \times E T_{0}
$$

Keterangan :

$\mathrm{K}_{\mathrm{c}}=$ koefisien tanaman, menunjukkan karakteristik spesifik tanaman;

$E T_{0}=$ evapotranspirasi tetapan/referensi yang tergantung dari faktor iklim.

Evapotranspirasi potensial dihitung dengan metode Penman modifikasi, dengan menggunakan persamaan (Doorenbos \& Pruit, 1976) :

$$
\begin{gathered}
\mathrm{ET}_{\mathrm{o}}=\mathrm{c}\left(\mathrm{w} \mathrm{R}_{\mathrm{n}}\right)+(1-\mathrm{w}) \mathrm{f}(\mathrm{u})(\mathrm{Ea}-\mathrm{Ed}) \\
\mathrm{R}_{\mathrm{s}}=\left(0,25+0,50 \frac{\mathrm{n}}{\mathrm{N}}\right) \mathrm{R}_{\mathrm{a}} \\
\mathrm{R}_{\mathrm{n}}=\mathrm{R}_{\mathrm{s}}-\mathrm{R}_{\mathrm{n}+1} \\
\mathrm{f}(\mathrm{t})=\sigma \cdot \mathrm{Ta}^{4}\left({ }^{\circ} \mathrm{C}\right) \\
\mathrm{f}(\mathrm{u})=0,27(1+0,864 \mathrm{u})(\mathrm{m} / \text { detik }) \\
\mathrm{E}_{\mathrm{d}}=\mathrm{E}_{\mathrm{a}} \times \mathrm{Rh}
\end{gathered}
$$

Keterangan :

$$
\begin{aligned}
& \text { Eto = Evapotranspirasi }(\mathrm{mm} / \mathrm{hari}) \text {; } \\
& \mathrm{w} \quad=\text { Suatu faktor yang berhubungan } \\
& \text { dengan temperatur; } \\
& \mathrm{R}_{\mathrm{s}} \quad=\text { Radiasi gelombang pendek; } \\
& \mathrm{R}_{\mathrm{a}} \quad=\text { Radiasi gelombang pendek yang } \\
& \text { memenuhi batas luar atmosfir } \\
& \text { (angka angot); } \\
& \mathrm{R}_{\mathrm{n} 1} \quad=\text { Radiasi gelombang panjang } \\
& \text { (mm/hari); } \\
& \mathrm{R}_{\mathrm{n}} \quad=\text { Total radiasi bersih ( } \mathrm{mm} / \text { hari); } \\
& \mathrm{f}(\mathrm{t}) \quad=\text { Fungsi suhu/konstanta bolzman; } \\
& \mathrm{n}=\text { Penyinaran matahari terukur, } \\
& \text { jam/hari. } \\
& \mathrm{N}=\text { = Penyinaran matahari maksimum } \\
& \text { yang mungkin terjadi pada suatu } \\
& \text { tempat dan waktu, jam/hari; }
\end{aligned}
$$

Optimasi Pola Tanam Pada Lahan Sawah Tadah Hujan Di Kecamatan Cimanggung Kabupaten 


$$
\begin{aligned}
\mathrm{f}(\mathrm{u}) & =\begin{array}{l}
\text { Fungsi kecepatan angin pada } \\
\text { ketinggian } 2 \mathrm{~m} ;
\end{array} \\
(\mathrm{E}-\mathrm{Ed})= & \begin{array}{l}
\text { Perbedaan tekanan uap jenuh } \\
\text { dengan uap sebenarnya, yang }
\end{array} \\
& \text { dinyatakan dalam mbar; } \\
\mathrm{Ea} & \text { Tekanan uap jenuh (mbar); } \\
\mathrm{Ed} & =\text { Tekanan uap sebenarnya (mbar); } \\
\mathrm{Rh} & \text { Kelembaban udara relatif }(\%) ; \\
\mathrm{C} & = \\
& \text { Angka koreksi Penman yang } \\
& \text { besarnya melihat kondisi siang dan } \\
& \text { malam. }
\end{aligned}
$$

\section{3) Analisis Neraca Air}

Analisis neraca air dilakukan dengan mengkaji seluruh hasil perhitungan ketersediaan air dan kebutuhan air tanaman tiap bulan. Metode neraca air yang digunakan adalaah metode neraca air umum yang dianalisis berdasarkan data-data klimatologi dan bermanfaat untuk mengetahui berlangsungnya periode basah (surplus air) dan periode kering (kekurangan air) pada suatu wilayah secara umum (Nasir, 2002).

Analisis neraca air terlebih dahulu dilakukan terhadap jadwal dan pola tanam yang biasa ditanam petani setempat (eksisting), kemudian memperbaiki jadwal dan pola tanam eksisting yang memiliki periode kekurangan air maupun kelebihan air yang cukup banyak dengan cara merubah waktu tanam atau mengganti jenis tanaman dengan tujuan untuk mengoptimalkan ketersediaan air yang masih berlebih.

\section{4) Penentuan Pola dan Jadwal Tanam}

Pola dan Jadwal tanam dirumuskan sesuai dengan keseimbangan neraca air di lahan kering. Pola dan jadwal tanam tersebut disimulasikan dalam analisis neraca air sesuai dengan keadaan eksisting pertanian daerah penelitian. Penetapan pola dan jadwal tanam yang direkomendasikan dilihat dari nilai neraca air yang dirasa cukup memenuhi kebutuhan air tanaman atau defisit air tidak terlalu besar, batas toleransi sebesar $20 \%$ dengan asumsi bahwa pada kondisi tersebut ketersediaan air masih ada.

\section{5) Optimasi Pola Tanam dengan Program Linier \\ Optimasi pola tanam dilakukan dengan tujuan untuk menentukan pola tanam mana}

yang dapat menghasilkan keuntungan maksimum bagi petani. Tiga langkah dalam memformulasikan model pemrograman linier, yaitu :

a. Menentukan variabel keputusan yang ingin diketahui, kemudian gambarkan dengan simbol-simbol aljabar.

b. Menentukan semua keterbatasan atau kendala dan gambarkan dalam bentuk persamaan atau pertidaksamaan linier dari variabel keputusan tadi.

c. Menentukan kriteria atau tujuan dan gambarkan dalam bentuk fungsi linier dari variabel keputusan tadi (maksimasi/minimasi).

Fungsi Program Linear (Yuwono, 2007) :

a. Fungsi tujuan : mengarahkan analisa untuk mendeteksi tujuan perumusan masalah.

b. Fungsi kendala : untuk mengetahui sumber daya yang tersedia dan permintaan atas sumberdaya tersebut.

Optimasi pemrograman linier untuk pola tanam dilakukan dengan menggunakan LiPS (Linear Program Solver) yaitu suatu perangkat lunak yang digunakan untuk menyelesaikan persoalan riset operasi, yang meliputi jawaban untuk fungsi tujuan dengan mempertimbangkan kendala atau batasan yang ada.

\section{HASIL DAN PEMBAHASAN}

\section{Kondisi Lahan sawah Tadah Hujan Kecamatan Cimanggung}

Lahan sawah tadah hujan di Kecamatan Cimanggung memiliki luas 77 ha. Musim Tanam I (MT I) dilakukan pada bulan Oktober dasarian II dan petani serentak menanam padi sedangkan Musim Tanam II (MT II) sebagian besar dilakukan pada Februari dasarian III, namun ada pula yang menanam di luar waktu tersebut karena perbedaan jenis tanaman yang ditanam pada MT II.

\section{Pola dan Jadwal Tanam Eksisiting}

Petani lahan sawah tadah hujan di Kecamatan Cimanggung umumnya menanam 2 (dua) kali dalam setahun. Berikut merupakan beberapa pola tanam eksisting dalam setahun 
yang terdapat di Kecamatan Cimanggung berdasarkan wawancara dengan petani :

Eksisiting I : Padi-Padi

Eksisiting II : Padi-Jagung

Eksisiting III : Padi-Tembakau

Eksisiting IV : Padi-Timun

Eksisiting V : Padi-Ubi Jalar

Sedangkan jadwal tanam eksisting

Kecamatan Cimanggung adalah sebagai berikut:

\begin{tabular}{lll}
\hline Pola Tanam & \multicolumn{1}{c}{ MT I } & \multicolumn{1}{c}{ MT II } \\
\hline Eksisting I & : Okt II - Jan I & Jan III - Apr III \\
\hline Eksisting II & : Okt II - Jan I & Jan III - Mei I \\
\hline Eksisting III & : Okt II - Jan I & Jan III - Mei I \\
\hline Eksisting IV & : Okt II - Jan I & Jan III - Mei II \\
\hline Eksisiting V & : Okt II - Jan I & Jan III - Mei II \\
\hline
\end{tabular}

Musim Tanam I (MT I) petani serempak menanam padi mengingat pada waktu tersebut merupakan awal musim hujan dimana ketersediaan air sedang tinggi.Musim Tanam II merupakan saat dimana ketersediaan air mulai berkurang. Keadaan tersebut digunakan petani untuk menanam tanaman yang tidak membutuhkan banyak air seperti palawija, walaupun ada beberapa petani yang menanam kembali padi dengan beberapa pertimbangan.

\section{Data Curah Hujan}

Data curah hujan yang diperoleh memiliki panjang data 14 tahun yaitu dari tahun 2002 sampai tahun 2015. Data tersebut diperoleh dari 3 (tiga) stasiun yaitu, stasiun Cicalengka, Rancaekek dan Jatiroke.Berikut adalah grafik curah hujan rata-rata bulanan pada masingmasing stasiun.

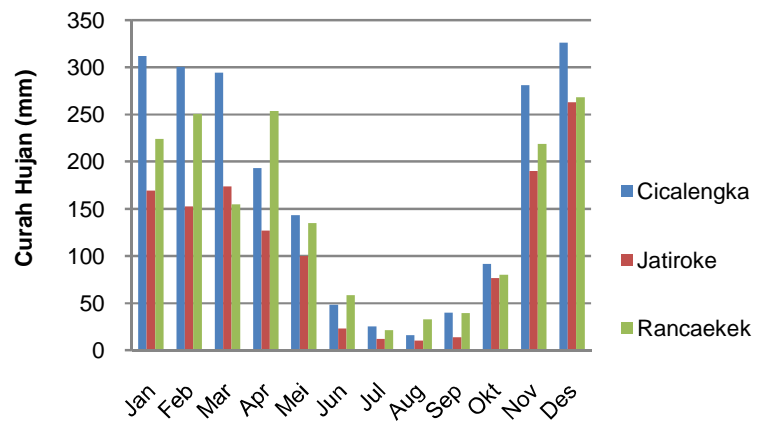

Gambar 2. Grafik Curah Hujan Rata-rata Bulanan Tiap Stasiun Hujan Tahun 2002-2015
Berdasarkan Gambar 2 di atas, dapat disimpulkan bahwa Bulan Basah (BB), yaitu saat jumlah curah hujan yang lebih dari $100 \mathrm{~mm} /$ bulan terjadi mulai dari bulan November sampai bulan Mei, sedangkan Bulan kering (BK) dimana jumlah curah hujan kurang dari $60 \mathrm{~mm} /$ bulan terjadi pada bulan Juni sampai bulan September. Sementara itu, bulan Oktober memiliki curah hujan kurang dari $100 \mathrm{~mm} /$ bulan namun lebih dari $60 \mathrm{~mm} /$ bulan, sehingga curah hujan tersebut tidak termasuk klasifikasi Bulan Basah (BB) maupun Bulan Kering (BK), sehingga bulan ini dapat dikatakan sebagai Bulan Lembab (BL).

\section{Data Klimatologi}

Data klimatologi diperoleh dari Loka Pengamatan Dirgantara (LPD) Sumedang dengan panjang data selama 10 tahun terakhir, yaitu dari tahun 2006 hingga 2015. Data klimatologi tersebut diperlukan untuk perhitungan nilai evapotranspirasi potensial.

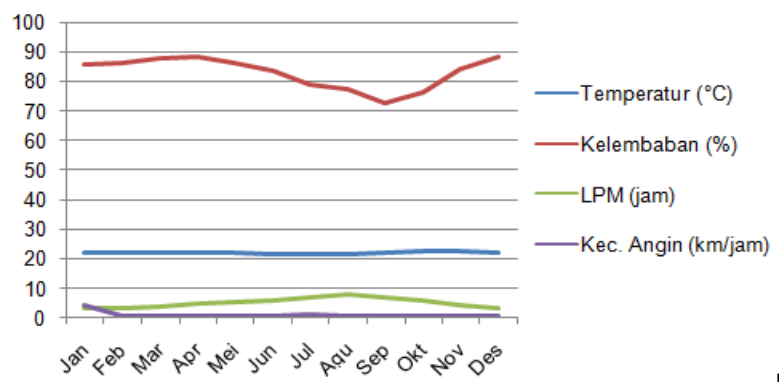

Gambar 3. Klimatologi Bulanan Rata-rata Tahun 2002-2015

Temperatur daerah penelitian berkisar antara 21-23 ${ }^{\circ} \mathrm{C}$. Kelembaban udara mencapai $88,56 \%$, lama penyinaran matahari berkisar antara 3-8 jam, dan kecepatan angin tertinggi mencapai angka $4,20 \mathrm{~km} / \mathrm{jam}$.

\section{Analisis Ketersediaan Air}

Ketersediaan air di lahan adalah air tersedia di lahan yang dapat digunakan tanaman untuk memenuhi kebutuhan airnya yang berasal dari curah hujan.

\section{Analisis Curah Hujan Wilayah}

Kecamatan Cimanggung tidak memiliki stasiun pengamatan hujan, sehingga untuk menentukan besar curah hujannya perlu dilakukan perhitungan curah hujan wilayah. Metode yang digunakan untuk menghitung curah hujan wilayah adalah metode Poligon 
Thiessen. Pada metode ini digunakan sistem bobot, yaitu pemberian bobot pada masingmasing stasiun hujan yang mewakili luasan di sekitarnya yang kemudian dari pembobotan luasan tersebut dapat diketahui seberapa luas pengaruh dari masing-masing stasiun terhadap daerah yang diteliti. Berikut merupakan gambar poligon yang terbentuk pada Kecamatan Cimanggung.

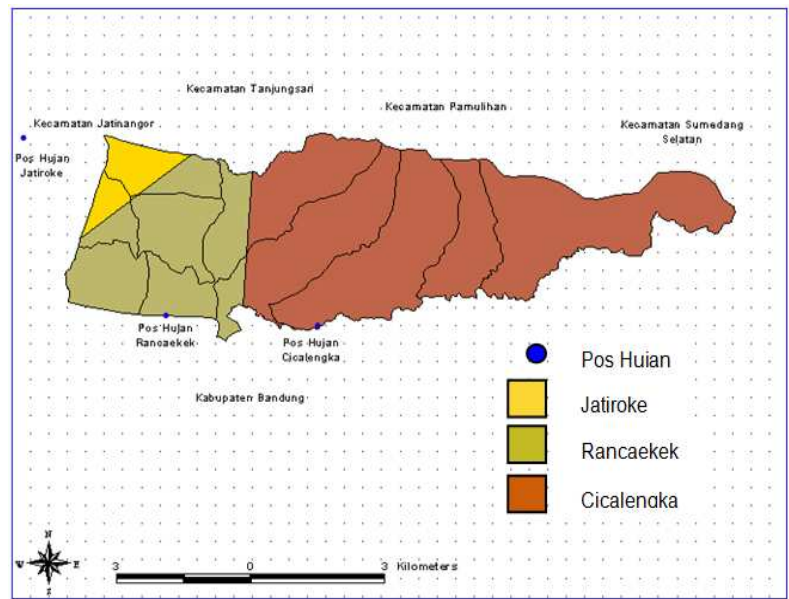

Gambar 4. Area Poligon Thiessen Kecamatan Cimanggung.

Stasiun hujan yang digunakan dalam perhitungan curah hujan wilayah Kecamatan Cimanggung adalah stasiun hujan Cicalengka, Rancaekek dan Jatiroke. Penentuan stasiunstasiun tersebut ditentukan berdasarkan titik lokasi stasiun yang dapat dibentuk menjadi poligon. Tiga warna berbeda pada Gambar 4 menunjukkan luas daerah jangkauan masingmasing stasiun hujan. Dengan kata lain hujan yang terjadi di luasan tersebut dianggap sama dengan hujan yang terjadi di stasiun terdekat. Berikut merupakan tabel yang menunjukkan luasan daerah jangkauan masing-masing stasiun. Berikut merupakan persentase luas jangkauan tiap stasiun dari luas total Kecamatan Cimanggung sebesar 4217,98 $\mathrm{m}^{2}$ :

$$
\begin{array}{ll}
\text { Jatiroke } & : 4,93 \% \\
\text { Rancaekek : } 27,01 \% \\
\text { Cicalengka : } 68,06 \%
\end{array}
$$

Stasiun Cicalengka memilki persentase luasan Kecamatan Cimanggung yang paling besar yaitu sebesar 68,06\%. Hal tersebut menunjukkan bahwa curah hujan wilayah.
Kecamatan Cimanggung sebagian besar memiliki curah hujan yang sama dengan curah hujan yang terjadi di stasiun Cicalengka.

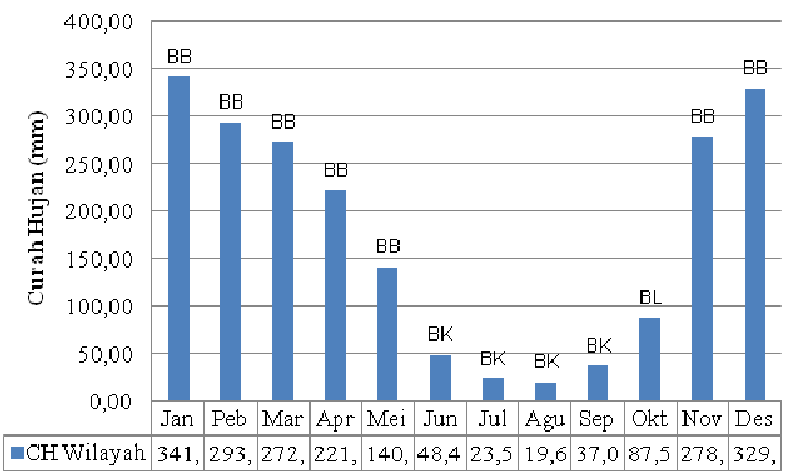

Gambar 5. Curah Hujan Wilayah Rata-rata Kecamatan Cimanggung

Berdasarkan Gambar 5 curah hujan wilayah rata-rata terkecil terjadi pada bulan Juli, sedangkan curah hujan wilayah terbesar terjadi pada bulan Desember. Sama halnya dengan curah hujan bulanan pada tiga stasiun, curah hujan wilayah memiliki periode Bulan Basah (BB) yang terjadi pada bulan November sampai Mei, periode Bulan Kering (BK) terjadi pada bulan Juni sampai bulan September, dan periode Bulan Lembab (BL) pada bulan Oktober. Dengan demikian dapat dikatakan bahwa hasil perhitungan curah hujan wilayah dengan hasil curah hujan pada setiap stasiun tidak memiliki perbedaan yang signifikan.

\section{Curah Hujan Efektif}

Curah hujan efektif dihitung dengan metode USDA Soil Conservation System. Sebaran kondisi curah hujan efektif dapat dilihat pada Gambar 6. Awal musim hujan ditandai dengan jumlah curah hujan dasarian sebesar $50 \mathrm{~mm}$ dan diikuti oleh minimal 2 (dua) dasarian berikutnya (BMG, 2008). Dasarian yang menunjukkan jumlah curah hujan $\leq 50 \mathrm{~mm}$ adalah dasarian I pada bulan November yang memiliki jumlah curah hujan $50,99 \mathrm{~mm}$. Oleh karena itu, bulan November dasarian I dapat dikatakan sebagai awal musim hujan. 


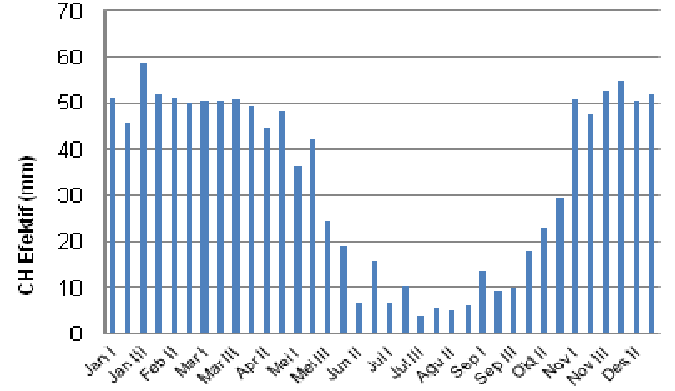

Gambar 6. Curah Hujan Efektif Dasarian Kecamatan Cimanggung

\section{Analisis Kebutuhan Air Tanaman}

Besarnya kebutuhan air tanaman dinyatakan sama dengan besarnya evapotranspirasi tanaman yang diperoleh dari hasil perkalian evapotranspirasi potensial (ETo) dan nilai koefisien tanaman (Kc). Evapotranspirasi potensial dihitung dengan metode Penman modifikasi.

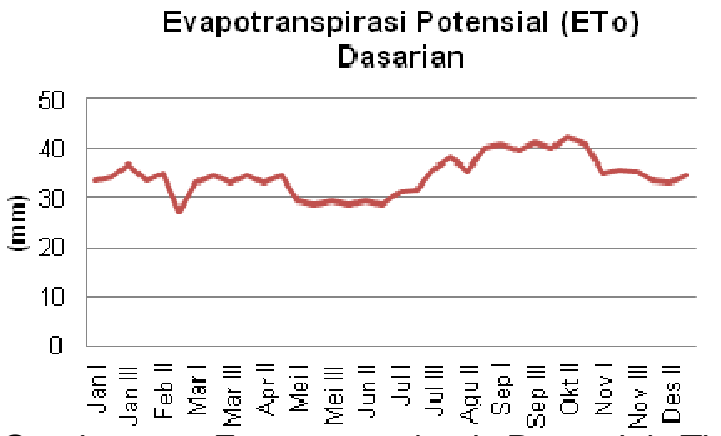

Gambar 7. Evapotranspirasi Potensial Tiap Periode

Berdasarkan Gambar 7 dapat diketahui besarnya evapotranspirasi potensial yang paling tinggi terjadi pada periode Oktober II yaitu sebesar $42,30 \mathrm{~mm}$, sedangkan nilai evapotranspirasi potensial paling rendah terjadi pada periode Februari III sebesar 27,03 $\mathrm{mm}$.

\section{Analisis Pola Tanam dan Neraca Air}

Perbandingan ketersediaan air dengan kebutuhan air tanaman pada pola dan jadwal tanam eksisiting, dimana awal tanam MT I adalah pada Oktober dasarian II, dapat dilihat pada uraian berikut :

Pola Tanam (MT I - MT II)

Padi-Padi : Terjadi defisit air yang

\begin{tabular}{|c|c|c|}
\hline \multicolumn{3}{|c|}{ Pola Tanam (MT I - MT II) } \\
\hline & & $\begin{array}{l}\text { melebihi batas toleran } \\
\text { pada awal penanaman } \\
\text { padi, yaitu pada Okt II dan } \\
\text { Okt III. }\end{array}$ \\
\hline Padi - Jagung & & $\begin{array}{l}\text { Terjadi defisit air yang } \\
\text { melebihi batas toleran } \\
\text { pada awal penanaman } \\
\text { padi, yaitu pada Okt II dan } \\
\text { Okt III. }\end{array}$ \\
\hline $\begin{array}{l}\text { Padi } \\
\text { Tembakau }\end{array}$ & & $\begin{array}{l}\text { Terjadi defisit air yang } \\
\text { melebihi batas toleran } \\
\text { pada awal penanaman } \\
\text { padi, yaitu pada Okt II dan } \\
\text { Okt III. }\end{array}$ \\
\hline Padi - Timun & & $\begin{array}{l}\text { Terjadi defisit air yang } \\
\text { melebihi batas toleran } \\
\text { pada awal penanaman } \\
\text { padi, yaitu pada Okt II dan } \\
\text { Okt III. }\end{array}$ \\
\hline Padi - Ubi jalar & & $\begin{array}{l}\text { Terjadi defisit air yang } \\
\text { melebihi batas toleran } \\
\text { pada awal penanaman } \\
\text { padi, yaitu pada Okt II dan } \\
\text { Okt III. }\end{array}$ \\
\hline
\end{tabular}

Sedangkan pada pola dan jadwal tanam alternatif, dimana jadwal tanamnya digeser sehingga awal tanam MT I adalah pada bulan November dasarian I. Berikut adalah uraian analisis pola tanam alternatif :

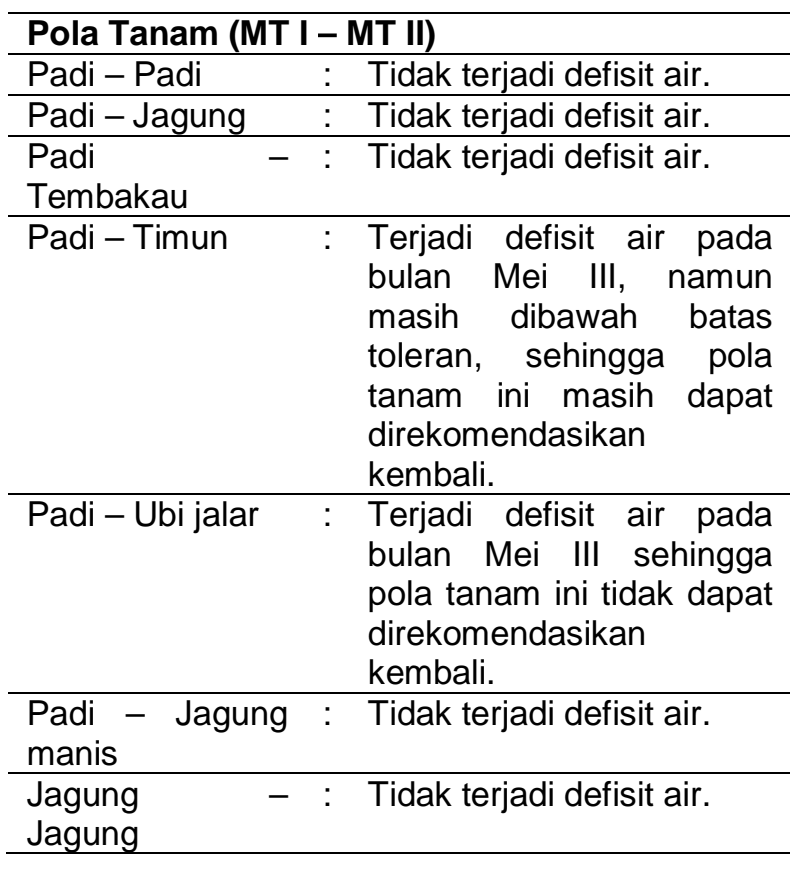


Berdasarkan analisis diatas maka pola tanam yang dapat dilakukan analisis optimasi adalah pola tanam yang tidak mengalami defisit air melebihi batas toleran sebesar $20 \%$. Oleh karena itu, tanaman yang dapat ditanam pada MT I adalah padi dan jagung, sedangkan tanaman yang memungkinkan dapat ditanam pada MT II adalah padi, jagung, tembakau, timun, dan jagung manis.

\section{Optimasi Pola Tanam}

Model matematis dalam analisis optimasi terdiri dari dua fungsi, yaitu :

\section{a. Fungsi Tujuan}

Tujuan yang akan dicapai dalam penelitian ini adalah keuntungan yang sebesar-besarnya yang diperoleh dari kegiatan pertanian. Untuk menentukan fungsi tujuan, harus diketahui peubah mana yang ingin diketahui nilai maksimumnya. Oleh karena itu, dalam fungsi tujuan digunakan peubah/variabel pendapatan usaha tani. Berikut merupakan pendapatan usaha tani yang dapat dihasilkan :

\begin{tabular}{cccccc}
\hline $\begin{array}{c}\text { Rata-Rata } \\
\text { Produks } \\
\text { (ton/ha) }\end{array}$ & $\begin{array}{c}\text { Harga } \\
\text { Produksi } \\
\text { (Rp/ton) }\end{array}$ & $\begin{array}{c}\text { Hasil } \\
\text { Produksi } \\
\text { (Rp/ha) }\end{array}$ & $\begin{array}{c}\text { Biaya } \\
\text { Produksi } \\
\text { (Rp/ha) }\end{array}$ & $\begin{array}{c}\text { Keuntungan } \\
\text { (Rp/ha) }\end{array}$ & Tanaman \\
\hline 3,5 & 5.300 .000 & 18.550 .000 & 5.860 .000 & 12.690 .000 & Padi \\
3,5 & 3.000 .000 & 9.100 .000 & 4.250 .000 & 4.850 .000 & Jagung \\
0,8 & 35.000 .000 & 28.000 .000 & 9.930 .000 & 20.065 .000 & Tembakau \\
14,0 & 2.000 .000 & 28.000 .000 & 7.230 .000 & 20.770 .000 & Timun \\
4,9 & 3.500 .000 & 14.700 .000 & 5.230 .000 & 9.470 .000 & $\begin{array}{c}\text { Jagung } \\
\text { manis }\end{array}$ \\
\hline
\end{tabular}

Pendapatan dari masing-masing komoditi pertanian tersebut dapat digunakan sebagai variabel fungsi tujuan dalam analisis optimasi. Fungsi tujuan terbagi menjadi fungsi tujuan untuk Musim Tanam I dan Musim Tanam II.Pada MT I terdapat dua jenis tanaman yang ditanam yaitu padi dan jagung, oleh karena itu jumlah variabel yang digunakan adalah 2 (dua). Sedangkan pada MT II terdapat 5 jenis tanaman sehingga jumlah variabel dalam fungsi tujuan adalah 5 (lima).

- Fungsi tujuan untuk MT I : $Z_{\max }=A X_{1}+B X_{2}$

- Fungsi tujuan untuk MT II :

$Z_{\max }=A X_{1}+B X_{2}+C X_{3}+D X_{4}+E X_{5}$

Keterangan :

$Z_{\text {max }}=$ Keuntungan maksimum kegiatan pertanian $(R p)$;

$A=$ Pendapatan hasil produksi padi (Rp);

$\mathrm{B}=$ Pendapatan hasil produksi jagung (Rp);
C = Pendapatan hasil produksi tembakau (Rp);

$\mathrm{D}=$ Pendapatan hasil produksi timun (Rp);

$\mathrm{E}=$ Pendapatan hasil produksi jagung manis (Rp);

$\mathrm{X}_{1}=$ Luas tanam padi (ha);

$X_{2}=$ Luas tanam jagung (ha);

$\mathrm{X}_{3}=$ Luas tanam tembakau (ha);

$\mathrm{X}_{4}=$ Luas tanam timun (ha);

$\mathrm{X}_{5}=$ Luas tanam jagung manis (ha).

\section{b. Fungsi kendala}

Fungsi kendala dalam penelitian ini adalah luas lahan sawah tadah hujan.Luas lahan sawah tadah hujan di Kecamatan Cimanggung sebesar 77 ha. Luas lahan tersebut pada MT I digunakan untuk menanam padi dan jagung, dan pada MT II dengan luas lahan yang sama sebesar 77 ha digunakan untuk menanam padi, jagung, tembakau, timun, dan jagung manis. Berikut adalah persamaan fungsi kendala setiap musim tanam :

- Fungsi kendala untuk MT I :

$\mathrm{X}_{1}+\mathrm{X}_{2} \leq \mathrm{X}_{\mathrm{t}}$

- Fungsi kendala untuk MT II :

$\mathrm{X}_{1}+\mathrm{X}_{2}+\mathrm{X}_{3}+\mathrm{X}_{4}+\mathrm{X}_{5} \leq \mathrm{X}_{\mathrm{t}}$

\section{Optimasi Musim Tanam I}

- Fungsi tujuan :

$$
Z_{\max }=12.690 .000 X_{1}+4.850 .000 X_{2}
$$

- Fungsi kendala :

$$
\mathrm{X}_{1}+\mathrm{X}_{2} \leq 77
$$

Hasil analisis optimasi dengan bantuan perangkat lunak LiPS (Linear Program Solver) diperoleh solusi optimal sebagai berikut :

$$
\begin{aligned}
& \text { Padi }=77 \text { ha; } \\
& \text { Jagung }=0 \text { ha. }
\end{aligned}
$$

Berdasarkan luasan tersebut dihasilkan keuntungan produksi tanam sebesar $\mathrm{Rp}$ $977.130 .000,00$. Nilai keuntungan tersebut merupakan pendapatan maksimum yang dapat diperoleh pada MT I. Pendapatan maksimum dapat dicapai apabila jenis tanaman yang ditanam pada MT I adalah padi dengan luas tanam sebesar 77 ha tanpa adanya penanaman jagung.

\section{Optimasi Musim Tanam II}

- Fungsi tujuan :

$$
\begin{aligned}
Z_{\max }= & 12.690 .000 X_{1}+4.850 .000 X_{2}+ \\
& 20.065 .000 X_{3}+20.770 .000 X_{4}+ \\
& 9.470 .000 X_{5}
\end{aligned}
$$

- Fungsi kendala :

44 Optimasi Pola Tanam Pada Lahan Sawah Tadah Hujan Di Kecamatan Cimanggung Kabupaten Sumedang 


$$
\mathrm{X}_{1}+\mathrm{X}_{2}+\mathrm{X}_{3}+\mathrm{X}_{4}+\mathrm{X}_{5} \leq 77
$$

Hasil analisis optimasi dengan bantuan perangkat lunak LiPS (Linear Program Solver) diperoleh solusi optimal sebagai berikut :

Padi $\quad=0$ ha;

Jagung $=0$ ha;

Tembakau = 0 ha;

Timun $=77 \mathrm{ha}$;

Jagung Manis $=0$ ha.

Pendapatan maksimum dapat diperoleh apabila pada MT II seluruh lahan ditanami dengan timun. Dengan demikian keuntungan yang dihasilkan dari penanaman timun pada luasan lahan sebesar 77 ha adalah sebesar Rp 1.599.290.000,00. Berdasarkan hasil analisis optimasi, keuntungan maksimum yang dapat diperoleh adalah dengan penanaman padi pada MT I dan penanaman timun pada MT II. Dengan kata lain pola tanam Padi-Timun adalah pola tanam optimal yang dapat menghasilkan keuntungan maksimum per tahun sebesar $=\mathrm{Rp}$ $977.130 .000,00+R p$ 1.599.290.000,00 $=R p$ 2.576.420.000,00 dari luas lahan sebesar 77 ha.

Kenyataan di lapangan menunjukkan kurangnya minat petani untuk menanam timun. Menurut hasil wawancara dengan petani, harga timun sering anjlok karena hasil panen yang besar tidak seiring dengan permintaan pasar, oleh karena itu petani tidak ingin mengambil resiko untuk menanamnya. Sebagian besar petani di Kecamatan Cimanggung lebih memilih menanam tembakau atau jagung pada saat Musim Tanam II (MT II) dengan pertimbangan bahwa tembakau memiliki harga jual yang tinggi, sementara jagung dapat dijual kering untuk mengantisipasi anjloknya harga pada saat panen.

\section{KESIMPULAN}

Berdasarkan analisis kesetimbangan air, jadwal tanam yang terbaik untuk Kecamatan Cimanggung adalah November dasarian II untuk Musim Tanam I (MT I) dan Februari dasarian III untuk Musim Tanam II (MT II) dengan pola tanam : Padi-Padi; Padi-Jagung; PadiTembakau; Padi-Timun; Padi-Jagung Manis; dan Jagung-Jagung. Berdasarkan analisis optimasi, dari pola tanam yang direkomendasikan, yang memberikan keuntungan maksimum adalah Padi-Timun.
Terima kasih kepada :

1. Petani lahan sawah tadah hujan Kecamatan Cimanggung Kabupaten Sumedang.

2. Pemerintah Kecamatan Cimanggung Kabupaten Sumedang, Jawa Barat.

3. Dinas Pengelolaan Sumber Daya Air (PSDA) Jawa Barat, atas data curah hujan yang digunakan dalam penelitian ini.

4. Balai Pengelolaan Daerah Aliran Sungai (BPDAS) Jawa Barat, atas peta Sub-DAS yang digunakan untuk perhitungan curah hujan wilayah.

5. Loka Pengamatan Dirgantara (LPD) Sumedang, atas data klimatologi yang digunakan untuk perhitungan evapotranspirasi.

Terima kasih pula kepada seluruh pihak yang telah membantu yang tidak bisa disebutkan satu per satu.

\section{DAFTAR PUSTAKA}

BMG. 2008. Prakiraan Musim Hujan 2008/2009 di Indonesia. Badan Meteorologi dan Geofisika. Jakarta.

Doorenbos, R.J. dan W.O. Pruit. 1976. Agrometeorological Field Station Irrigation and Drainage Paper no 27. FAO. Rome.

Kecamatan Cimanggung. 2009. Data Base Profil Kecamatan Cimanggung.Cimanggung.

Nasir, A.2002. Neraca Air Agroklimatik, Makalah Pelatihan Bimbingan Pengamanan Tanaman Pangan dan Bencana Alam.Bogor

Pramudia, A., Nasrullah dan Alemina, E., 1991. Sumber Daya Iklim Sebagai Dasar Analisis Perencanaan Pertanian di Pulau Lombok. Simposium Perhimpi III Malang, 20 - 22 Agustus 1991.

Talitha, Juan. 2010. Studi Optimasi Pola Tanam pada Daerah Irigasi Jatiroto dengan Menggunakan Program Linier. [Skripsi] Jurusan Teknik Sipil. Fakultas Teknik Sipil dan Perencanaan. Institut Teknologi Sepuluh Nopember. Surabaya.

Yuwono, B. 2007.Bahan Kuliah Riset Operasional. Jurusan Teknik Informatika. Fakultas Teknologi Industri. UPN Veteran.Yogyakarta.

\section{Ucapan Terima Kasih}

